\title{
A Fair Hearing Requirement for Union Trusteeships under the LMRDA
}

The constitutions of many labor unions authorize the international to impose a trusteeship ${ }^{1}$ over subordinate units ${ }^{2}$ - usually union locals. ${ }^{3}$ Although designed as a device to combat corruption and mismanagement, trusteeships have also been used to raid locals' treasuries and install corrupt officers for the international's benefit. Except for a purely procedural fair hearing requirement, the common law placed few re-

1 Cox, The Role of Law in Preserving Union Democracy, 72 HARv. L. REv. 609, 635 (1959). Professor Cox states the accepted definition of a trusteeship as a labor organization's suspension of the autonomy of and assumption of control over a subordinate body. This broad definition was adopted in LMRDA, $\S 302,29$ U.S.G. $\S 462$ (1970). For a discussion of the number of international constitutions that authorize the use of trusteeships, see note 3 infra. See generally Beaird, Union Trusteeship Provisions of the Labor-Management Reporting and Disclosure Act of 1959, 2 GA. L. REv. 469, 502-10 (1968), which explains the conceptual problems created by the adoption of this broad definition.

2 The relationship and functions of the various tiers of the usual labor union structure - the local, district council, and international-is explained in T. KHEEx, LABOR LAW, 18 BUSINESS ORGANIZATIONS, \$\$ \$.01-3.02 (1972). See generally J. BARBASH, LABOR's GRASS ROOTS $131-45$ (1961).

8 Most trusteeships are imposed by internationals upon locals, but trusteeships can also be imposed by internationals upon district councils, see, e.g., Hodgson v. UMW, 344 F. Supp. 990 (D.D.C. 1972), affd sub nom., Brennan v. UMW, 475 F.2d 1293 (D.C. Cir. 1973), or by district councils over locals. Although there are no examples of this latter type of trusteeship, section 302 of the LMRDA, 29 U.S.C. $\$ 462$ (1970), clearly permits a district council to impose a trusteeship on a subordinate body.

In 1959, only 67 of 114 major internationals had trusteeship provisions in their constitutions. H. Cohany \& I. Philips, Union Constrtutional Provisions: Trusteeshrps 9 (Bureau of Labor Statistics Bull. No. 1263, 1959). No union constitution prohibited trusteeships, and all granted international officers general powers that could be invoked to impose trusteeships. Id. at 2-3. Unfortunately the Bureau of Labor Statistics states that, due to lack of funds, it has no more recent statistics. Letter from Mr. John Murphy, Office of Labor-Management and Welfare Pension Reports, Jan. 31, 1973, on file at The University of Chicago Law Review.

In 1962, of 110 major internationals, 57 , comprising 52 percent of the union labor force, had no trusteeship hearing requirement in their constitutions. SECRETARY OF LABOR, Union Trusteeshirs: A REPORT To Congress 99 (Table 4-3) (1962) [hereinafter referred to as SEC'Y OF LABOR'S REPORT]. These statistics also have not been updated. Letter from Leonard Lurie, Director, Office of Labor-Management and Welfare Pension Reports, Jan. 26, 1978, on file at The University of Chicago Law Review.

A 1968 study found that of 43 international unions surveyed, 19 had changed their trusteeship provisions since the enactment of the LMRDA: seven added a hearing requirement for suspension of the local's autonomy; all seven, however, provided an exception to this requirement for emergencies, which could be declared by the president, executive board, or both. Ross \& Taft, The Effects of the LMRDA Upon Union Constitutions, 43 N.Y.U.L. REv. 305, 325 (1968). 
strictions on the international's power to impose trusteeships. To control the abuse-prone trusteeship power, ${ }^{4}$ Congress in 1959 enacted Title III of the Labor Management Recording and Disclosure Act (LMRDA). 5

This comment considers two questions: whether, absent a hearing requirement in the labor organization's constitution or bylaws, ${ }^{6}$ the LMRDA invalidates a trusteeship imposed without a fair hearing; and, if a hearing is required, when it must be held.

\section{The Fair Hearing Requirement}

The common law trusteeship rules and the purpose of the LMRDA suggest that a trusteeship imposed without a fair hearing should be considered invalid.

\section{A. The Common Law Background}

Prior to the enactment of the LMRDA, courts held that imposing a trusteeship without a hearing was tantamount to enforcing a confiscatory bylaw of a voluntary association, ${ }^{7}$ and constituted a taking of members' property without due process. ${ }^{8}$ The "fair hearing" requirement was enforced irrespective of silence ${ }^{9}$ or contrary requirements in the international constitution. ${ }^{10}$ In particular, the international was required to provide the local with notice and a statement of specific

4 See text and notes at notes 17-23 infra.

5 LMRDA $\$ \S 301-06,29$ U.S.C. $\$ \S 461-66$ (1970). For a discussion of the relationship of the LMRDA to other federal labor legislation and the labor movement, see S. CoHEN, LABOR LAW 186-98 (1964).

6 No problem is raised where the constitution of the international provides for hearings, because the Act requires that trusteeships be established in accordance with the labor organization's constitution and bylaws. In 1962, 57 out of 110 international constitutions studied contained hearing provisions for authorization or ratification. SEc'Y OF LABOR's REPORT, supra note 3, at 99 (Table 4-3).

7 Hotel and Restaurant Employees Local $458 \mathrm{v}$. Hotel and Restaurant Employees Int'l, 212 Minn. 587, 4 N.W.2d 771 (1941); Swaine v. Miller, 72 Mo. App. 446 (1897); Neal v. Hutcheson, 160 N.Y.S. 1007 (Sup. Ct. 1916).

8 Ellis v. AF of L, 48 Cal. App. 2d 440, 444, 120 P.2d 79, 81 (1941); Kennedy v. Schroeder, 35 N.Y.S.2d 835, 838 (Sup. Ct. 1942), rev'd on other grounds, 265 App. Div. 725, 40 N.Y.S.2d 611 (1943); Mursener v. Forte, 186 Ore. 253, 269, 205 P.2d 568, 575 (1949).

9 Hotel and Restaurant Employees Local 458 v. Hotel and Restaurant Employees Int'l, 212 Minn. 587, 592, 4 N.W.2d 771, 775 (1942); Swaine v. Miller, 72 Mo. App. 446 (1897); Neal v. Hutcheson, 160 N.Y.S. 1007, 1010 (Sup. Ct. 1916).

10 Garcia v. Ernst, 101 N.Y.S.2d 693 (Sup. Ct. 1950); Kennedy v. Schroeder, 35 N.Y.S.2d 835 (Sup. Ct. 1942), rev'd on other grounds, 265 App. Div. 725, 40 N.Y.S.2d 611 (1943); Bricklayers' Union v. Bowen, 183 N.Y.S. 855 (Sup. Ct. 1920); Mursener v. Forte, 186 Ore. 153, 205 P.2d 568 (1949). 
charges, ${ }^{11}$ opportunity to present a defense, ${ }^{12}$ and intraunion appeal..$^{13}$ Only procedural fairness was reviewed by the courts, however, and the common law hearing requirement thus provided only very limited protection to the locals. The substantive findings of the hearing officers, who were personnel of the international serving in both prosecutorial and judicial roles, were not reviewed..$^{14}$ In Fanara $v$. Teamsters, ${ }^{15}$ for example, the New York Supreme Court held a trusteeship invalid because the international had not presented specific charges to the lo$\mathrm{cal}$. After the international met the procedural requirement, however, the court validated the trusteeship, specifically refusing to consider substantive attacks on its validity. ${ }^{16}$

\section{B. Enactment of the LMRDA}

In 1957 the inadequacy of the common law trusteeship rules came to the attention of the McClellan Committee. ${ }^{17}$ The Committee discovered, among other abuses of power, that internationals imposed trusteeships as a means of seizing the assets of locals, ${ }^{18}$ installing cor-

11 Hotel and Restaurant Employees Local 458 v. Hotel and Restaurant Employees Int'1, 212 Minn. 587, 592, 4 N.W.2d 771, 775 (1942).

12 Bricklayers' Union v. Bowen, 183 N.Y.S. 855,859 (Sup. Ct. 1920).

13 Garcia v. Ernst, 101 N.Y.S.2d 693, 697 (Sup. Ct. 1950). For examples of appeal procedures, see the procedure in the constitution of the Laborers' International Union of North America, described in Plentty v. Laborers' Int'l, 302 F. Supp. 332, 335 (E.D. Pa. 1969), and in the constitution of the International Brotherhood of Electrical Workers Union, described in IBEW Local 1186 v. Eli, 307 F. Supp. 495 (D. Hawaii 1969). The local's rights do not include the right to counsel at the hearing. Id. at 510. Either a member of the local or its officers can initiate an action to enforce the hearing requirement. Compare Garcia v. Ernst, supra, with Bricklayers' Union v. Bowen, 183 N.Y.S. 855 (Sup. Ct. 1920) and Ellis v. AF of L, 48 Cal. App. 2d 440, 120 P.2d 79 (194I). Injunctive relief was usually sought. E.g., Reiser v. Kralstein, 26 LRRM 2014, aff'd on rehearing, 26 LRRM 2264 (N.Y. Sup. Ct. 1950).

14 Combining the prosecutorial and judicial functions recently has been held not to violate the fair hearing requirement. Parks v. IBEW, 314 F.2d 886, 912 (4th Cir. 1963); IBEW Local 1186 v. Eli, 307 F. Supp. 495, 508 (D. Hawaii 1969).

1533 LRRM 2592 (N.Y. Sup. Ct. 1954).

1634 LRRM 2714 (N.Y. Sup. Ct. 1954).

17 The Select Committee on Improper Activities in the Labor or Management Field ("McClellan Committee") issued three reports: S. REP. No. 1417, 85th Cong., 2d Sess., (1958) (First Interim Report); S. Rep. No. 621, 86th Cong., 1st Sess. (1959) (Second Interim Re. port); and S. REP. No. 1139, 86th Cong., 2d Sess. (1960) (Final Report). The Final Report was published after the enactment of the LMRDA, therefore only the Interim Reports could have influenced the trusteeship legislation. The hearings consisted of an investigation of three unions: the Teamsters, the Bakery Workers, and the Operating Engineers. For a criticism of the committee's findings on the grounds that three internationals were insufficient to draw a legislative conclusion from, see S. REP. No. 1417, supra, at 458-59 (Individual Views of Sen. Pat McNamara).

18 See S. Rep. No. 1417, supra note 17, at 438, 447. 
rupt leadership, ${ }^{19}$ using the locals as pawns in intraunion battles, ${ }^{20}$ and depriving members of their right to self-government for long periods. ${ }^{21}$ Although procedural fairness was not the primary focus of the hearings, ${ }^{22}$ testimony before the Committee indicated that even the minimal common law procedural safeguards were not always respected. ${ }^{23}$ In response to these problems, the Committee recommended legislation that would limit the purposes for which trusteeships could be established. ${ }^{24}$

During the legislative hearings on the LMRDA, it became apparent that the procedural safeguards provided by the common law fair hearing requirement were insufficient. ${ }^{25}$ Both the Senate and the House Committee Reports on Title III state in identical language: "The legal theory applied by courts is often inadequate. A trusteeship will ordinarily be set aside unless the local is given a fair hearing including notice of the charges and an opportunity to defend. But if the forms of fair procedure are observed there appears to be little the courts can do...." 28

Title III reflects the McClellan Committee's conclusions ${ }^{27}$-each substantive regulation corresponding to a specific problem uncovered by the Committee. ${ }^{28}$ To eliminate baseless imposition of trusteeships, Title III recognizes only four purposes for which trusteeships are to be considered legitimate: "correcting corruption or financial malpractice, assuring the performance of collective bargaining agreements or other duties of a bargaining representative, restoring democratic procedures, or otherwise carrying out the legitimate object of such labor organization." 29 To prevent looting of locals, the Act forbids any transfer of funds during a trusteeship, except for per capita assessments from

19 See id. at $420,447$.

20 See id. at 447.

21 See id. at $371,420,438,447$.

22 See id. at 425; S. REP. No. 621, supra note 17, at 58.

23 S. Rep. No. 1417, supra note 17, at 1. The Committee's conclusions concerning the use of trusteeships do not mention the need for procedurally fair hearings. Id. at 4 .

24 See id.

25 See Hearings on Union Financial and Administrative Practices and Procedure Before the Subcomm. on Labor of the Senate Comm. on Labor and Public Welfare, 85 th Cong., 2d Sess. 608 (1958).

26 S. Rep. No. 187, 86th Cong., 1st Sess. 17 (1959); H.R. REP. No. 741, 86th Cong., 1st Sess., 13 (1959).

27 S. REP. No. 1417, supra note 17 , at 4 .

28 Id.; see S. REP. No. 1139, supra note 17 , at 869 , where the report comments that the LMRDA served the purpose for which the Select Committee originally had been constituted. See SEC'Y of LABOR'S REPORT, supra note 3, at 11.

29 LMRDA § 302, 29 U.S.C. \$ 462 (1970). 
the local to the international. ${ }^{30}$ Finally, to prevent the manipulation of locals in union political battles, Title III prohibits the election of union officials or delegates to union conventions unless all local members in good standing are allowed to vote by secret ballot. ${ }^{31}$ The substantive protections provided by the LMRDA can be enforced by the Secretary of Labor or any member of the local in federal district court, ${ }^{32}$ and are to be "in addition to any and all other rights and remedies at law or in equity." 33

A trusteeship established for one of the approved purposes, in conformity with the constitution and bylaws of the labor organization, and authorized or ratified after a fair hearing is presumed valid for eighteen months. ${ }^{34}$ Thereafter there is a presumption of invalidity. The statute does not indicate, however, the status to be accorded a trusteeship imposed for a valid purpose without a hearing, or under what circumstances the courts are to presume valid a trusteeship imposed with only a postimposition, or "ratification," hearing. ${ }^{35}$

The ambiguity surrounding the status of such trusteeships under the LMRDA should be resolved by incorporation of the common law hearing requirement into the statute. As the foregoing discussion of the LMRDA indicates, such judicial construction would be consistent with

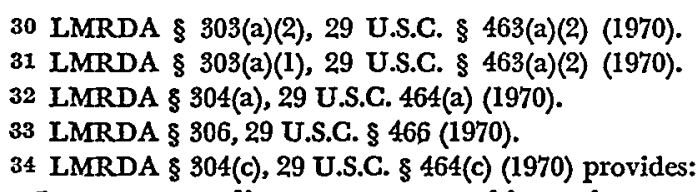

In any proceeding pursuant to this section a trusteeship established by a labor organization in conformity with the procedural requirements of its constitution and bylaws and authorized or ratified after a fair hearing either before the executive board or before such other body as may be provided in accordance with its constitution or bylaws shall be presumed valid for a period of eighteen months from the date of its establishment and shall not be subject to attack during such period except upon clear and convincing proof that such trusteeship was not established or main. tained in good faith or for a purpose allowable under section 462 of this title. After the expiration of eighteen months the trusteeship shall be presumed invalid in any such proceeding and its discontinuance shall be decreed unless the labor organization shall show by clear and convincing proof that the continuation of the trusteeship is necessary for a purpose allowable under section 302. In the latter event the court may dismiss the complaint or retain jurisdiction of the cause on such conditions and for such period as it deems appropriate.

The primary purpose behind this section was to limit the duration of trusteeships. S. REP. No. 187, supra note 26, at 17; H.R. REP. No. 741, supra note 26, at 13; see Haydanek, Comments, in Symposium on THE LABor-Manangement REporting aND Disclosure Act of 1959, at 469, 470 (R. Slovenko ed. 1959); Beaird, supra note 1, at 516-17; Moss, Union Trusteeships: Title III of the Labor-Management Reporting and Disclosure Act of 1959, 4 SuFFoLK L. REv. 1, 32 (1969); Note, Landrum-Griffin and the Trusteeship Imbroglio, 71 YALE L.J. 1460, 1501 (1962). The Act was generally successful in accomplishing this goal. Of the 487 trusteeships active on the date of the enactment, 312 were more than eighteen months old; two-and-one-half years later only 74 of 187 active trusteeships were over eighteen months in duration. SEC'Y OF LABOR's REPORT, supra note 3, at 84.

35 LMRDA § 304(c), 29 U.S.C. 464(c) (1970). 
the legislative purpose of Title III. ${ }^{36}$ Several courts have taken this approach, but it is only one of four ways that courts have dealt with fair hearing requirements under the Act.

\section{Judicial Interpretation of the Fair Hearing Requirement After Enactment of the LMRDA}

1. The Four Approaches Taken by the Courts. First, some courts have held that, because section 302 requires conformity with the labor organization's internal regulations, a hearing cannot validate a trusteeship under a constitution or bylaws that are silent or vague on procedures for trusteeship imposition. ${ }^{37}$ In Flight Engineers International v. Continental Airlines, ${ }^{38}$ the court held that the common law powers of an international to place a local in trusteeship were nullified by the enactment of the LMRDA. This holding rested on the Senate Report's concurrence in the McClellan Committee's finding that national legislation was needed to limit the right of internationals to impose trusteeships. ${ }^{39}$ The international's constitution contained no trusteeship establishment procedure, and the court concluded that a valid trusteeship could not, therefore, be imposed. Other cases have held that, even if the labor organization's constitution grants general trusteeship powers to the international, a trusteeship is not valid if the authorizing language is vague. The Tenth Circuit Court of Appeals, for example, has read section 302 as permitting the international to impose a trusteeship only if its constitution or bylaws provide explicit and fair procedures. ${ }^{40}$

A second approach taken by courts has involved a literal reading of section 304(c) so as to view a fair hearing as affecting only the presumption of validity granted to a trusteeship. IBEW Local $1186 v$. Eli ${ }^{41}$ denied injunctive relief to a local union seeking removal of a trusteeship

86 See S. REP. No. 187, supra note 26, at 17; H.R. REP. No. 741, supra note 26, at 13. The lone dissenter was George Meany, who stated: "Procedurally, Senator Kennedy's bill requires only that the union follow its own constitution, while the courts require in addition, that its constitutional procedure be fair, provide notice and hearing, etc. In this respect the bill seems to be taking a step backwards." Hearings on Union Financial and Administrative Practices and Procedure, supra note 25, at 68.

37 United Bhd. of Carpenters v. Brown, 343 F.2d 872, 882 (10th Cir. 1965); Flight Eng'rs Int'1 v. Continental Airlines, 297 F.2d 397, 402-03 (9th Cir. 1961), cert. den., 369 U.S. 871 (1962); Smith v. Distillery Workers, 75 LRRM 2049, 2051 (E.D. Ky. 1970); Local 2, Tel. Workers v. IBEW, 261 F. Supp. 433 (D. Mass. 1966); see Sawyer v. Grand Lodge, Int'1 Ass'n of Machinists, 279 F. Supp. 747, 753 (E.D. Mo. 1967) (trusteeship held valid only after the court determined that the international constitution was sufficiently specific.)

88 Flight Eng'rs Int'l Continental Airlines, 297 F.2d 397 (9th Cir. 1961).

39 Id. at 402 .

40 United Bhd. of Carpenters v. Brown, 343 F.2d 872, 882 (10th Cir. 1965).

41307 F. Supp. 495 (D. Hawaii 1969). 
that had been imposed without a hearing. The suit was held premature on the grounds that the local had not exhausted its right of internal union appeal. ${ }^{42}$ Relying on Congress's failure explicitly to make a hearing mandatory, and contending that any other construction would make sections 302 and 304(c) redundant, the court stated that noncompliance with section 304(c)'s hearing requirement precludes only the presumption of the trusteeship's validity. ${ }^{43}$ The court rejected the local's contention that $304(\mathrm{c})$ placed absolute restrictions on the power of internationals to impose trusteeships. ${ }^{44}$

Third, courts have held that both the legislative history of section 304(c) and basic policy considerations absolutely require a hearing for the establishment of a valid trusteeship. ${ }^{45}$ In Local 2, Telephone Workers v. International Brotherhood of Telephone Workers, ${ }^{46}$ a local sought to enjoin suspension of its charter, an action determined by the court to constitute imposition of a trusteeship. The trusteeship was ruled invalid on the grounds that the international's constitution contained inadequate procedures for imposing a trusteeship ${ }^{47}$ and the international had not held a fair hearing as implicitly required in section $304(\mathrm{c}) \cdot{ }^{48}$

Fourth, some courts have noted that, in light of Title III, the LMRDA should be construed as incorporating the common law hearing requirement. ${ }^{49}$ This interpretation, although effectively the same as the third approach, avoids reliance on the ambiguous language and legislative history of the section. ${ }^{50}$ This approach was adopted to avoid establishing an enigmatic third category of trusteeships-neither presumed valid under section 304 (c) nor held invalid under section $302^{51}$ -

$42 I d$. at 510 .

$43 I d$. at 502 .

$44 \mathrm{Id}$. at $50 \mathrm{l}-03$.

45 Local 13410, UMW v. UMW, 475 F.2d 906, 913-15 (D.G. Cir. 1973); see Eames, The Relationship between International and Local Unions, 15 ANNUAL N.Y.U. CoNFERENCE ON LABOR 23, $30 \mathrm{n} .5$ (1962) (the presumption of validity is raised "if and only if there is a fair hearing. ..."). The text of section $304(\mathrm{c})$, note 34 supra, does not, however, directly support this reading.

40261 F. Supp. 433 (D. Mass. 1966).

$47 I d$. at 435 .

$48 I d$. at 436 .

40 Bailey v. Dixon, 429 F.2d 1321 (5th Cir. 1970); Jolly v. Gorman, 428 F.2d 960, 966-67 (5th Cir. 1970), aff'g 304 F. Supp. 15 (S.D. Miss. 1969); Luggage Workers Local 167 v. International Leather Workers, 316 F. Supp. 500, 505-06 (D. Del. 1970); Plentty v. Laborers' Int'l, 302 F. Supp. 332 (E.D. Pa. 1969).

50 The Fifth Circuit and district courts in Pennsylvania and Delaware based this interpretation on Congress's knowledge of the pre-LMRDA common law requirement and the express legislative intent to increase court control over trusteeship imposition. See cases cited note 49 supra.

51 Luggage Workers Local 167 v. International Leather Workers, 316 F. Supp. 500, 505. 
to which courts would have to apply a standard not provided in the statute. ${ }^{52}$

The fourth approach is the wisest. Construing Title III as incorporating the common law hearing requirement is consistent with the legislative history, purpose, and substantive protection of the Act. ${ }^{53}$ This interpretation also helps preserve employees' rights to choose their bargaining representatives, and minimizes the burdens of litigation on the courts, the local, and the international.

2. Interrelation Between Hearings and the Substantive Protections of the LMRDA. The substantive protections added by the LMRDA cannot be regarded as substitutes for the common law procedural safeguard of a fair hearing. ${ }^{54}$ The importance of several aspects of the hearing requirement is in fact increased by the LMRDA limitations on the power of internationals to impose trusteeships. First, the need for a full hearing record is increased. Before enactment of the LMRDA, the courts needed very little evidence to review the imposition of

52 Id. at 504.

53 This construction of the Title III hearing requirement is more consistent with Congress's intent than is the harsh requirement, set down in Flight Engineers, that a valid trusteeship cannot be imposed without clear procedures in the international's constitution or bylaws. See text at notes 37-38 supra. Congress recognized the useful role that a legitimately imposed trusteeship can perform: "These trusteeships are among the most effective devices which responsible international officers have to ensure order within their organization." S. REP. No. 187, supra note 26, at 16; H.R. REP. No. 741, supra note 26, at 13. It appears unlikely, therefore, that Congress meant to limit the ability of an international to impose a trusteeship on one of its locals by imposing a strict requirement of procedural explicitness. The Department of Labor has concluded that an international's constitution and bylaws need not contain procedures for the imposition of a trusteeship. SEG'Y OF LABOR's REPORT, supra note 3, at 36. See also IBEW Local 1186 v. Eli, 307 F. Supp. 495, 503-04 (D. Hawaii 1969); Moss, supra note 34, at 17. Moreover, section 302 restricts the international's power to impose a trusteeship, but does not specify the procedures by which they must be established. Cf. 105 CoNG. REc. 6677 (1959) (remarks of Senator Erwin, cosponsor of the Kennedy-Erwin bill, S. 505, that the trusteeship provisions of their bill intended to preserve as far as possible internal union control over union affairs. S. 505 was substantially identical to the LMRDA as enacted. See SEC'Y OF LABOR's REPORT, supra note 3 , at $145-47$ ).

54 The statutory language and legislative history of sections 302 and 304 (c) bar any interpretation that would read 304(c) into 302 so as to define their combined requirements as a complete listing of the requisites of a valid trusteeship. Cf. Moss, supra note 34, at 17; Note, supra note 34, at 1504. Section 302 lists the requirements for imposing a trusteeship, while section 304(c) does not mention either presumptions of validity or absolute invalidity where a hearing is not held. Nor does the legislative history suggest that the sections are to be read together. Rather, it indicates that their purposes are different. Section 302 was intended to limit the purposes of trusteeships; section 304(c), to limit their duration. H.R. ReP. No. 741, supra note 26, at 13-14. Reading the two sections together also renders redundant the language in $304(\mathrm{c})$ concerning compliance with the international's constitution and bylaws. See IBEW Local 1186 v. Eli, 307 F. Supp. 495, 502 (D. Hawaii 1969). 
trusteeships because the discretion permitted internationals in such matters was very broad. ${ }^{55}$ To determine whether there has been compliance with the limitations of the LMRDA, however, the reviewing court needs a full record. ${ }^{56}$

Second, by permitting the local to refute the purposes stated by the international in its specific charges and to raise rebuttal evidence against the need for a trusteeship, a fair hearing aids the local in insuring that the international is not using the label of a proper purpose to cover an improper one, ${ }^{57}$ misusing the broad fourth purpose of section 302 - "otherwise carry out the legitimate purpose of such labor organization"68_or simply acting on incorrect information.

Congressional intent to encourage procedural fairness is clear from the provision in section 304 (c) granting an eighteen month presumption of validity where the international holds a fair hearing.59 The statute should not be read, however, as merely denying the presumption of validity where a trusteeship is imposed without a hearing. ${ }^{60}$ Under

65 E.g., Fanara v. Teamsters, 33 LRRM 2592, 34 LRRM 2714 (N.Y. Sup. Ct. 1954), discussed in text at notes 15-16 supra.

56 Plentty v. Laborers' Int'l, 302 F. Supp. 332, 340 (E.D. Pa. 1969).

67 See Horowitz, Possible Effects of LMRDA's Trusteeship Provisions, in SYMPosium on the Labor-Management Recording and Disclosure AGt of 1959, at 458, 460 (R. Slovenko ed. 1961). For discussion of the danger that the hearing body might be a rubber stamp for the international, see Parks v. IBEW, 314 F.2d 886, 912 (4th Cir. 1962); Summers, Legal Limitations on Union Discipline, 64 Harv. L. REv. 1049, 1083 (1951); Summers, American Legislation for Union Democracy, 25 Mod. L. REv. 273, 282-89 (1969); Weber, Local Trusteeship and Public Policy, 14 IND. AND LAB. REL. REv. 185, 204 (1960).

58 LMRDA § 302,29 U.S.C. \$ 462 (1970). During the enactment of the LMRDA, Senator Goldwater stated that he considered this fourth purpose so broad as to nullify the restrictions of the other three. 105 CoNG. REc. 10100 (1959); see Note, supra note 34, at 1500-01. Seventy-five percent of all trusteeships imposed were reported to the Secretary of Labor as coming under this fourth purpose. SEC'Y OF LABOR's REPORT, supra note 3, at 61.

59 Prior to the enactment of the LMRDA, there was a common law right to a fair hearing for a union member threatened with expulsion. Underwood v. Maloney, 152 F. Supp. 648 (E.D. Pa. 1957), rev'd on other grounds, 256 F.2d 334 (3d Cir. 1958); Neal v. Hutcheson, 160 N.Y.S. 1007 (Sup. Ct. 1916). It has been argued that because this right was specifically incorporated into the statute, LMRDA \& 101(a)(5), 29 U.S.C. \& 411(a)(5) (1970), Congress's failure specifically to incorporate the common law trusteeship hearing requirement indicates that there was a congressional intent to eliminate that requirement. See Moss, supra note 34, at 34. A comparison of the purpose of LMRDA Title III-protection of union members through substantive rather than procedural limitations on trusteeships, see note 5 supra, note 65 infra, and text at notes 28, 32-33 supra-with the purpose of LMRDA Title I-preservation of union democracy, H.R. Rep. No. 741, supra note 26 , at 7-however, explains the omission of a procedural norm as a requirement in Title III. Accord, Plentty v. Laborers' Int'l, 302 F. Supp. 332, 339 (E.D. Pa. 1969), where the court argued that Congress could not have intended to require a hearing in the less significant case where an individual is punished or censored, yet not in the more important case involving displacement of democratically elected officers. Id. at 339.

60 SEC'Y OF LABOR's REPORT, supra note 3, at 36. The Secretary of Labor's position is that the fair hearing should be mandatory for all impositions of trusteeships. Id. 
such an interpretation, internationals could be expected in each case to compare the benefits of holding a hearing with the detriments of not holding one. A hearing would delay imposition of the trusteeship but would give the international's action the presumption of validity; omitting the hearing would permit immediate imposition but would cause a loss of the presumption. In cases where immediate imposition of the trusteeship would cause substantial hardship to the local or would neutralize the local during a crucial period of controversy, the option of avoiding a preimposition hearing would provide the international with a powerful weapon. ${ }^{\text {Bd }}$

3. Democratic Control of Local Unions. Incorporation of the common law hearing requirement into Title III also implements the legislative purpose of section 7 of the Labor Management Relations Act (LMRA) ${ }^{62}$ and section 101(a)(1) of the LMRDA. ${ }^{63}$ Both sections guarantee to employees a right, although not absolute, to bargain collectively through representatives of their choosing. Courts have held that the LMRDA was intended both to minimize international interference with local affairs ${ }^{64}$ and to encourage democratic selection of the local's leadership. ${ }^{65}$ Nonetheless, no court has held that displacement of local officials by a trustee violates the members' right to select their leaders. Suspension of this right, however, should be permitted only to avoid serious prejudice to the legitimate interests of the international and only after the local members are afforded an opportunity to defend their right to elect their own leadership. ${ }^{68}$ Members of local unions have a legitimate interest in preserving their autonomy against the international's power and control. ${ }^{67}$ The international, on the other hand, must be able to control and discipline locals. ${ }^{68} \mathrm{~A}$ hearing before

61 Emergencies must be an exception to the rule of preimposition hearings. See text at notes 105-14 infra.

62 "Employees shall have the right to self-organization, to form, join, or assist labor organizations, to bargain collectively through representatives of their own choosing, and to engage in other concerted activities for the purpose of collective bargaining or other mutual aid or protection. . . ." LMRA § 7, 29 U.S.C. § 157 (1970).

6329 U.S.G. \& $411($ a)(I) (1970). Congress explicitly stated in section 302(b) of the LMRDA its intent to "afford necessary protection of the rights and interests of employees and the activities of labor organizations." 29 U.S.C. $\S 401(\mathrm{~b})(1970)$.

64 Navarro v. Gannon, 385 F.2d 512, 517-19 (2d Gir. 1967), aff'g 266 F. Supp. 601 (S.D.N.Y. 1967).

65 Monborne v. UMW, 342 F. Supp. 718, 723 (W.D. Pa. 1972).

68 See generally Local 13410, UMW v. UMW, 475 F.2d 906 (D.C. Cir. 1973).

67 See Hearings on Union Financial and Administrative Practices and Procedure, supra note 25, at 352 (testimony of Professor Cox); Horowitz, supra note 57, at 466; Summers, supra note 57, at 300; cf. Parks v. IBEW, 314 F.2d 886, 907-10 (4th Cir. 1963).

68 S. REP. No. 187, supra note 26 , at 17 ; H.R. REP. No. 741, supra note 26 , at 13; Cox, supra note 1 , at 635 . 
a body from the international provides an opportunity for the local to disprove the necessity for the loss of its autonomy and helps to assure its members that the suspension of their rights could not be avoided under the circumstances. ${ }^{69}$ Leaving the initial determination of the need for a trusteeship within the union assures the international necessary control, ${ }^{70}$ subject to court review.

4. Minimizing the Burdens of Litigation. Judicial incorporation of the common law fair hearing requirement would minimize litigation expense by providing a single forum for the local's grievance and by increasing the likelihood of disputes being settled out of court through consultation and negotiation between the local and the international. ${ }^{11}$

Section 306 leaves intact the members' right to bring a state court action against the international for failure to hold a hearing; ${ }^{72}$ section 304(a), however, limits enforcement of the substantive protections of Title III to the federal courts. ${ }^{73}$ If Title III is not interpreted as requiring a hearing for trusteeship imposition, the members or their locals seeking to wage both substantive and procedural attacks on the trusteeship may have to maintain separate actions in federal and state courts.

Pendant and protective jurisdiction do not provide adequate remedies for this problem. A pendant claim would be proper only if accompanied by a legitimate federal claim under the LMRDA. ${ }^{74}$ Failure to prove the federal claim might result in the dismissal of the state claim as well..$^{75}$ Moreover, the exercise of pendant jurisdiction is discretionary, so that the only safe course would be to bring actions in two courts simultaneously. ${ }^{76}$

Protective jurisdiction is inappropriate, in this situation, to alleviate the pressures toward multiforum litigation. The concept of protec-

69 The need for a trusteeship is determined by the hearing body based upon the evidence presented. See Plentty v. Laborers' Int'l, 302 F. Supp. 332, 340 (E.D. Pa. 1969).

70 Congress did not want "to allow much scope at this point for the Government to review the judgment of union officials. ..." S. REP. No. 187, supra note 26, at 18.

71 Local 13410, UMW v. UMW, 475 F.2d 906 (D.C. Cir. 1973).

72 LMRDA § 306, 29 U.S.G. 466 (1970); S. REP. No. 187, supra note 26, at 19; H.R. REP. No. 741, supra note 26, at 15 .

7329 U.S.C. \$ 464 (1970). The section also provides for the filing of a complaint by the Secretary of Labor. Section 306 provides that where the Secretary has filed a complaint, "the jurisdiction of the district court over such trusteeship shall be exclusive." Thus the problems of multiforum litigation arise only where the local or its members are the parties prosecuting the action.

74 Luggage Workers Local 167 v. International Leather Workers, 316 F. Supp. 500, 505 n.13 (D. Del. 1970).

75 Id.; see UMW v. Gibbs, 383 U.S. 715 (1966).

76 Cf. UMW v. Gibbs, 383 U.S. 715, 726 (1966). 
tive jurisdiction allows the federal courts to take jurisdiction of state law questions where Congress has created federal substantive jurisdiction in closely related areas. The device is justified as necessary to avoid conflicts between state and federal decisions. This approach was adopted in the concurring opinion of Mr. Justice Burton in Textile Workers $v$. Lincoln Mills, ${ }^{77}$ which involved the ability of federal district courts to fashion a remedy under section 301(a) of the Labor Management Relations Act. ${ }^{8}$ Under Title III of the LMRDA, however, Congress explicitly left state remedies intact, ${ }^{79}$ and therefore protective jurisdiction is inappropriate. ${ }^{80}$

A trusteeship hearing may allow the international to demonstrate to members of the local the propriety of the trusteeship, thus avoiding costly court litigation entirely. Where the local remains unconvinced, greater knowledge of the strengths and weaknesses of the opposing side's case, developed through the intraunion hearing, will increase the likelihood of a private settlement. ${ }^{81}$

\section{Timing of the Fair Hearing}

The fair hearing requirement would provide scant protection to a local union if the international could manipulate the timing of the hearing without limitation; yet there are circumstances in which it would be grossly unfair to demand that the international endure the delay of a hearing before imposing a trusteeship. In an emergency situation, the international should be allowed to delay the required hearing until after imposition of the trusteeship, but only for as long as is justified by the emergency.

\section{A. The Present State of the Law}

Courts generally have found that a hearing after imposition of the trusteeship can create the statutory presumption of validity. ${ }^{82}$ Some

77353 U.S. 448,459 (1957) (concurring opinion).

7829 U.S.C. § 185 (1970).

79 LMRDA $\S 306,29$ U.S.C. $\S 466$ (1970); S. REP. No. 187, supra note 26, at 19; H.R. REP. No. 741, supra note 26 , at 15 .

80 Cf. Textile Workers v. Lincoln Mills, 353 U.S. 448, 474-78 (1957) (Frankfurter, J., dissenting).

81 This is desirable because intraunion hearings are likely to be a less costly means of dispute settlement than litigation in the federal courts.

82 See text and notes at notes 83-90 infra. But see Bailey v. Dixon, 429 F.2d 1321 (5th Cir. 1970), where the Fifth Circuit affirmed a district court order enjoining imposition of a trusteeship before a fair hearing had been held, holding that the determination was within the lower court's discretion. After the hearing was held by the international, the preliminary injunction was dissolved. 314 F. Supp. 452 (E.D. La. 1970), aff'd, 451 F.2d 160 (5th Cir. 1971). The district court explained that the order was based on the necessity of a preimposition hearing. 314 F. Supp. 452, 453 (1970). 
courts have granted the presumption when fair hearings were held from seventeen to thirty days after imposition of a trusteeship. ${ }^{83}$ One court held that an eleven month lag was not too long to trigger the statutory presumption. ${ }^{84}$ Several courts have found trusteeships invalid because no fair hearings were held, but stayed injunctive relief to give the international time to hold a ratification hearing, and thereby gain the presumption of validity. ${ }^{85}$ These decisions do not, however, reveal whether postimposition hearings would be sufficient in all situations.

In $N A L C v$. Sombrotto, ${ }^{86}$ an international obtained an injunction to force recognition of a trusteeship by a local that was threatening both to strike illegally and to bind itself to a rival labor organization. The court held that, regardless of the existence of an emergency, a postimposition hearing could validate the trusteeship only if such procedure was specifically provided for in the union's constitution or bylaws. ${ }^{87}$ The preliminary injunction was granted contingent upon the international's holding a hearing as soon as possible on continuation of the trusteeship. ${ }^{88}$ In Local 13140, UMW v. UMW, ${ }^{89}$ the D.C. Circuit Court invalidated a trusteeship, holding that-absent reasonable grounds to believe an emergency exists-the hearing must be held before the trusteeship is imposed. The court added that in an emergency a hearing must be scheduled, at the time of imposition, for the earliest possible date after imposition, even if the international's constitution does not so require.90

83 Federal and City Service Employees Local 554 v. Service Employees Int'l, 327 F. Supp. 644 (N.D. Ga. 1970), affd, 441 F.2d 1115 (5th Cir. 1971) (hearing held seventeen days after imposition); IBEW Local 1186 v. Eli, 307 F. Supp. 495 (D. Hawaii 1969) (the hearing was held twenty-five days after the trusteeship imposition; the court upheld the trusteeship on grounds that the local had waived its right to object to the tardiness of the hearing by not doing so sooner, and that the local had failed to establish any prejudice by the delay); Local 238, Laborers' Int'l v. Fosco, 80 LRRM 2081 (E.D. Wash. 1972) (hearing held thirty days aftex imposition).

84 Jolly v. Gorman, 304 F. Supp. 15 (S.D. Miss. 1969), aff'd, 428 F.2d 960 (5th Cir. 1970).

85 Luggage Workers Local 167 v. International Leather Workers, 316 F. Supp. 500, 508 (D. Del. 1970) (injunctive relief stayed thirty days); Plentty v. Laborers' Int'l., 302 F. Supp. 382 (E.D. Pa. 1969) (injunctive relief stayed forty-five days).

86449 F.2d 915 (2d Cir. 1971).

87 Id. at 920.

$88 \mathrm{Id}$. at 923 .

80475 F.2d 906 (D.C. Cir. 1973).

$90 \mathrm{Id}$. at 915. The court did not address the definitional problem of what constitutes an emergency, stating only that "We can imagine extreme emergencies that might compel action without prior notice and hearing." Id. at 914-15; see text at notes 109-11 infra. A ratification hearing has been held not to validate the imposition of a trusteeship where the sole question the hearing determined was whether the trusteeship should be continued, because at such a hearing the local is denied its right to refute the grounds for the trusteeship's initiation. Smith v. Distillery Workers, 75 LRRM 2049, 2051-52 
Because judicial interpretations of the timing requirement for fair hearings differ, the language, history, and purpose of the LMRDA, as well as policy considerations and the preexisting common law must be examined to determine when ratification should be permitted instead of authorization, and how long a delay in holding the hearing should be allowed.

\section{B. The Language, History, and Purpose of the LMRDA}

The LMRDA provides only very limited guidance on the question of the timing of the required fair hearing. Section 304(c) grants a presumption of validity to trusteeships "authorized or ratified" by a fair hearing..$^{91}$ Long-standing canons of statutory interpretation require that the courts construe statutory language according to common usage, unless a technical meaning is explicitly indicated, and that the words be construed so as to avoid redundancy. In ordinary usage, to "ratify" is to legitimate an event after its occurrence. ${ }^{92}$ This interpretation also avoids redundancy in the phrase "authorized or ratified." 93 During the legislative hearings on the LMRDA, Professor Cox ${ }^{94}$ stated that this phrase was intended to enable the international to impose a trusteeship and validate it later through ratification..$^{95}$ Neither the statute nor its history, however, reveal what circumstances justify "ratification" instead of "authorization." 96 Although there are indications that Congress was aware of the general importance of procedural fairness when it passed the LMRDA, ${ }^{97}$ it is impossible to determine what specific limitations on ratification Congress may have contemplated. When faced

(E.D. Ky. 1970). See also IBEW Local 1186 v. Eli, 307 F. Supp. 495, 508-09 (D. Hawaii 1969). Contra NALC v. Sombrotto, 449 F.2d 915, 923 (2d Cir. 1971), where the court granted relief contingent upon a hearing being held on continuation of the trusteeship.

91 LMRDA \& 304(c), 29 U.S.C. \$ 464(c) (1970).

92 IBEW Local I186 v. Eli, 307 F. Supp. 495, 501 (D. Hawaii 1969).

83 $I d$. This interpretation is also supported by the commentators. E.g., Cox, supra note 1, at 642; Weber, supra note 57, at 204.

84 Professor Cox was Senator John Kennedy's chief drafting assistant in drafting the Kennedy-Exwin bill, S. 505, Title II of which eventually became Title III of the LMRDA. Isaacson, Union Trusteeship under the Landrum-Griffin Act, I4 N.Y.U. ANNUAL CONERRENCE ON LABOR 97, 103 (1961).

95 Hearings on Union Financial and Administrative Practices and Procedure, supra note 25, at 373. Professor Cox testified that the statute adopts the view that in "the rush of events," the trusteeship might be imposed before the hearing.

96 Both the Senate and House Reports, supra note 26 , are silent on the meaning of the two words.

97 S. REP. No. 187 , supra note 26 , at 18 ; H.R. REP. No. 741 , supra note 26 , at 14 . Both reports explain that $\S 304(c)$ was intended to encourage fair procedure. Accord, SEC'Y OF LABOR's REPORT, supra note 3, at 22; Moss, supra note 34, at 17 (although $\$ 302$ does not require fair procedure, $\$ 304$ (c) encourages it). 
with this ambiguity, courts should look to the common law and to the policies to be served by regulating the timing of the hearing.

\section{The Common Law Rule}

The prevailing common law position was that, under certain circumstances, the hearing requirement could be satisfied by a postimposition hearing. ${ }^{98}$ The courts divided, however, over precisely what those circumstances were. Some courts held that, if the international had reasonable grounds to impose a trusteeship, it could act before holding a hearing. ${ }^{90}$ These decisions generally did not consider how long after imposition of the trusteeship the hearing could be delayed, although the Supreme Court of Minnesota stated that unreasonable delay by the international would terminate the local's obligation to pursue an intraunion appeal before seeking judicial review. ${ }^{100}$

In two cases a New York court held a trusteeship invalid where the hearing had been held or was available after imposition. In Kennedy v. Schroeder, ${ }^{101}$ the New York Supreme Court held that imposition of a trusteeship and revocation of a local's charter without a prior hearing was a denial of due process of law. In Reiser $v$. Kralstein, ${ }^{102}$ the court restrained a trusteeship imposed on a local before a hearing where there was no evidence of an emergency-the only condition under which the union's constitution permitted such an action. The court also reasoned that since the initial imposition of the trusteeship was illegal, a continuation hearing was unfair to the members of the local. The court emphasized that the continuation hearing unfairly placed the burden of proof on the local to show the trusteeship invalid rather than on the international to prove justification. ${ }^{103}$

The inability of the courts, both before and after the enactment of the LMRDA, to agree on when the hearing must be held suggests that the determination should be based upon the policies to be served by regulating the timing of the hearing. These policies indicate that a

98 See, e.g., Hotel and Restaurant Employees, Local 458 v. Hotel and Restaurant Employees Int'1, 212 Minn. 587, 4 N.W.2d 771 (1942) (a trusteeship imposed before a hearing is valid when just grounds exist).

99 Id. But see Fanara v. Teamsters, 33 LRRM 2592, 34 LRRM 2714 (N.Y. Sup. Ct. 1954).

100 Hotel and Restaurant Employees Local 458 v. Hotel and Restaurant Employees Int'1, 212 Minn. 587, 600, 4 N.W.2d 771, 778 (1942).

10135 N.Y.S.2d 835, 838 (Sup. Ct. 1942).

10226 LRRM 2014, affd on rehearing, 26 LRRM 2264 (N.Y. Sup. Ct. 1950).

10326 LRRM 2264, 2265 (N.Y. Sup. Ct. 1950). See also Neal v. Hutcheson, 160 N.Y.S. 1007 (Sup. Ct. 1916), where the court held that a fair hearing must be held before suspension of a member or a local and the decision must not proceed from any presumption of correctness of the charge. 
limitation of postimposition ratification to emergency situations is the correct approach.

\section{Policy Considerations for Timing of Ratification Hearings}

As courts have recognized, both before and after enactment of the LMRDA, an absolute prohibition of trusteeships imposed before a hearing would, in some situations, produce very grave consequences for the international. In the absence of an emergency, however, there is little justification for allowing validation by ratification. The consequences of such action may prejudice the local significantly. ${ }^{\mathbf{1 0 4}}$

Although a slippery concept, "emergency" has been held to include these situations: an immediate strike vote; ${ }^{105}$ a local wildcat strike;100 and violation of a collective bargaining agreement, for which a $\$ 10$ million damage suit was brought against the international. ${ }^{107}$ These conditions warrant immediate suspension of the local's autonomy. If a prior hearing is required in such cases, the crisis very likely will not be averted.

Trusteeship hearings may take several weeks to hold.108 A fair hearing has been held to require that the local be given prior notice, ${ }^{109}$ time to prepare and present its case, ${ }^{110}$ and the right to cross-examine witnesses. ${ }^{111}$ Moreover, since section $304(c)^{112}$ requires the hearing to be held before either the executive board or another designated body of the international, ${ }^{113}$ the time needed to convene the hearing can cause further delay. ${ }^{114}$

If there are no reasonable grounds to believe that there will be serious

104 See text at note 61 supra. Most international constitutions permit the suspension or postponement of trusteeship hearings if the international's officers determine that the local problem is an emergency. Only 7 of 114 constitutions investigated by Cohany and Philips required a hearing before trusteeship establishment. H. CoHAny \& I. PHILrPs, supra note 3 , at 11 .

105 NALC v. Sombrotto, 449 F.2d 915 (2d Cir. 1971).

106 Local 238, Laborers' Int'l v. Fosco, 80 LRRM 2081 (E.D. Wash. 1972).

107 Jolly v. Gorman, 304 F. Supp. 15 (S.D. Miss. 1969), aff'd, 428 F.2d 960 (5th Cir. 1970).

108 E.g., Luggage Workers Local 167 v. International Leather Workers, 316 F. Supp. 500 (D. Del. 1970) (hearing procedure took twenty-five days to complete); IBEW Local 1186 v. Eli, 307 F. Supp. 495 (D. Hawaii 1969) (hearing took twenty-five days to hold and complete).

109 Luggage Workers Local 167 v. International Leather Workers, 316 F. Supp. 500 (D. Del. 1970).

110 Plentty v. Laborers' Int'l, 302 F. Supp. 392 (E.D. Pa. 1969).

111 Local 2, Telephone Workers v. IBTW, 300 F. Supp. 910 (D. Mass. 1970).

112 LMRDA \& 304(c), 29 U.S.C. \& 464(c) (1970).

113 Contra, Federal and City Service Employees Local 554, v. Service Employees Int'l, 327 F. Supp. 644 (N.D. Ga. 1970); Schonfeld v. Raferty, 271 F. Supp. 128 (S.D.N.Y.), aff'd, 381 F.2d 446 (2d Cir. 1967) (one hearing official held sufficient to constitute a body).

114 See, e.g., Luggage Workers Local $167 \mathrm{v}$. International Leather Workers, $316 \mathrm{~F}$. 
damage if the trusteeship imposition is delayed by a hearing, however, the international has no legitimate grounds for not holding a preimposition hearing. ${ }^{115}$ Ratification increases the likelihood that a hearing body will sustain the trusteeship without inquiring into the need for it. ${ }^{116}$ This jeopardizes the fairness of the imposition procedure and conflicts with the explicit intent of section 304 (c) as stated in both the Senate and House Reports. ${ }^{117}$ Moreover, where ratification is used in a nonemergency situation and the hearing body or a reviewing court determines that the trusteeship was unnecessary, the local members have been temporarily denied their right to democratic self-government without cause-contrary to the purpose of section 302 .

The same considerations indicate that where a ratification hearing is justified, it should be held as soon as possible after the trusteeship imposition. ${ }^{118}$ The international has no legitimate reason for delay beyond the needs of meeting the emergency and the local's interests are increasingly compromised the longer the hearing is postponed. If the trusteeship was established without a proper purpose or in bad faith, the local members' right of self-government was abridged for a longer period than required by the circumstances. The longer the hearing is delayed, the more likely that, when finally held, it will focus on continuation of the trusteeship rather than the reason for its imposition. ${ }^{119}$ This derogates the local's right to refute the grounds for imposition and saddles it with the more onerous burden of justifying termination of the trusteeship..$^{120}$

Supp. 500 (D. Del. 1970). The local claimed the obligation to travel was needlessly burdensome because the international could have held the hearing at a more convenient place. Id. at 508.

115 Local 13410, UMW v. UMW, 475 F.2d 906 (D.C. Cir. 1973).

116 Weber, supra note 57, at 204.

117 See text and note at note 97 supra. Accord, Hearings on Union Financial and Administrative Practices and Procedure, supra note 25, at 373 (testimony of Professor Cox).

118 Local 13410, UMW v. UMW, 475 F.2d 906, 914-15 (D.C. Cir. 1973). The court's suggestion in Local 13410 that the ratification hearing date should be set at time of imposition appears to be an extremely useful procedural protection.

110 Accord, Weber, supra note 57, at 204 (the sooner after ratification the hearing is held, the less likely the hearing officers will accept the trusteeship as a fait accompli).

120 See text and notes at notes 90, 101-02 supra. Hearings held as soon as practicable after the imposition of a trusteeship in an emergency situation should entitle the trusteeship to the presumption of validity, unless the international constitution or bylaws specifically call for an authorizing hearing. But see NALG v. Sombrotto, 449 F.2d 915, 920 (2d Cir, 1971) (ratification hearing permissible only if specifically provided for by the international's constitution). Since section 304(c) allows ratification unless it is procedurally inconsistent with the constitution and bylaws, and since the view that Title III requires certain procedures in international constitutions and bylaws has been rejected, see note 53 supra, the Second Circuit's position in Sombrotto imposes too strict a requirement. 


\section{Conclusion}

The common law fair hearing requirement should be judicially incorporated into Title III of the LMRDA. Except where an emergency situation exists, the courts should find any trusteeship imposed without a fair hearing invalid. In emergency situations, a ratification hearing should be required as soon as possible after the trusteeship is imposed. This procedure would serve Congress's intention to encourage fairness in union trusteeship practices without compromising the legitimate interests of either the local or the international.

Judicial incorporation of the fair hearing requirement would balance the interests of union members in preserving the autonomy of their locals with the interests of the internationals in maintaining control over subordinate units and preventing obstruction of their legitimate goals. Incorporation of the common law fair hearing requirement would regularize trusteeship procedures and thus reduce the costs to the public of intraunion disputes. 